\title{
Pengaruh Adsorben Sebagai Media Filter dalam Menurunkan Kadar Timbal dalam Matrik Air Sungai
}

\author{
Nurmeily Rachmawati ${ }^{1}$ \\ Poltekkes Kemenkes Banten \\ E-mail: nurmeily.rachmawati@gmail.com
}

\begin{abstract}
Abstrak
Usaha untuk mendapatkan air bersih dapat dilakukan dengan melakukan proses filterisasi. Salah satu sumber air yang dimanfaatkan untuk mendapatkan air bersih adalah air sungai. Sungai Cisadane yang terletak di Kota Tangerang ditemukan kadar logam timbal dengan kadar yang melebihi ambang batas baku mutu. Oleh sebab itu diperlukan suatu usaha untuk menurunkan kontaminan logam timbal dalam air sungai tersebut. Tujuan penelitian ini yaitu mendapatkan informasi bagaimana adsorben alami dapat dimanfaatkan sebagai media filter dalam menurunkan kontaminan logam timbal tersebut. Metode penelitian ini merupakan ekperimental laboratorium dengan merancang media filter yang berisikan adsorben alami. Jumlah adsorben yang digunakan berjumlah 8 yaitu arang aktif (AA), zeolite (Z), sekam padi bakar (SPB), pasir silica (PS), jerami padi (JP), serbuk kayu (SK), sekam padi (SP), dan serabut kelapa (CH). Hasil yang diperoleh terjadi penurunan kontaminan logam berat dikedelapan adsorben yang digunakan. Adsorben zeolite, serbuk kayu, dan serabut kelapa mampu menurunkan kontaminan logam berat sebesar $90 \%$ dari konsentrasi awal logam timbal yang ditambahkan kedalam matrik air sungai tersebut. Berdasarkan uji statistic paired t-test juga ditemukan perbedaan yang nyata antara sebelum dan sesudah filterisasi di kedelapan adsorben tersebut yang ditunjukkan dengan nilai Sig (2-tailed) $<\alpha=0,025$.
\end{abstract}

Kata kunci: adsorben; logam timbal; media filtrasi

\begin{abstract}
Efforts to get clean water can be done by doing a filtration. One of the sources of water that is used to get clean water is river water. The Cisadane River, which is located in Tangerang City, has found levels of lead metal with that exceed the quality standard threshold. Therefore we need an effort to reduce lead metal contaminants in the river water. The purpose of this study is to obtain information on how natural adsorbents can be used as filter to reduce the contaminants of lead metal. This research method was laboratory experiment by designing filter that containing natural adsorbents. The number of adsorbents used is 8 , there were charcoal (AA), zeolite (Z), roasted rice husks (SPB), silica sand (PS), rice straw (JP), wood powder (SK), rice husks (SP), and coconut husk (CH). The results showed decreased heavy metal contaminants in the eight adsorbent. Zeolite, wood powder, and coconut fiber can reduce heavy metal contaminants by $90 \%$ from the initial concentration of lead metal that added to the river water as matrix. Based on the paired $t$-test, it showed a significant difference between before and after filtration on the eight adsorbents indicated by the value of Sig (2-tailed) $<\alpha=0.025$.
\end{abstract}

Keywords: adsorben; lead metal; filtration media 


\section{Pendahuluan}

Manusia memiliki kebutuhan primer dan sekunder dalam menjalankan kehidupan sehari-harinya. Salah satu kebutuhan manusia yang diperlukan adalah ketersediaan air bersih (Mifbakhudin, 2010). Kegiatan manusia yang membutuhkan air bersih diantaranya untuk keperluan mencuci, mandi, kebersihan rumah, taman, dan lain-lainnya (Fathur, 2019). Kebutuhan akan air bersih diperoleh dengan memanfaatkan sumber-sumber air yang ada. Salah satu sumber air yang dapat dimanfaatkan adalah air sungai. Menurut Bank Data Kualitas Lingkungan (DLHK) Kabupaten Tangerang yang rutin melakukan pemeriksaan kualitas air sungai di beberapa titik sampling anak sungai ditemukan kadar pencemaran melebihi ambang batas baku mutu pada tahun 2018. Salah satu pencemaran tersebut adalah logam timbal.

Faktor pencemaran tersebut dapat disebabkan oleh aktivitas manusia maupun oleh kondisi lingkungan sekitar. Zat-zat pencemar ini dapat mempengaruhi kualitas air dan membahayakan kesehatan tubuh. Beberapa zat pencemar diantaranya sedimen, garam, dan logam yang toksik (Wayan, 2015). Logam timbal memiliki efek toksisitas yang berbahaya terhadap tubuh manusia diantaranya menyebabkan kerusakan system saraf pusat, konstipasi, kolik pada system pencernaan, dan kematian janin pada ibu hamil (Fibrianti, 2015).

Untuk dapat dimanfaatkan sebagai sumber air bersih perlu dilakukan proses filterisasi untuk mengurangi zat kontaminan pada sumber air tersebut. Proses filtrasi air dapat dilakukan dengan menggunakan metode oksidasi, koagulasi, flokulasi, reverse osmosis, biosand filter, dan metode-metode lainnya (Ajeng, 2019). Salah satu diantara metode tersebut adalah dengan memanfaatkan konsep adsorben sebagai material penjerap kontaminan pada air. Material ini merupakan suatu adsorben yang memiliki rongga pori cukup besar sehingga mampu menjerap zat yang sesuai dengan karakterisitik adsorben tersebut.

Pemanfaatan media filter ini dapat menggunakan media filter yang terbuat dari bahan alami ataupun sintesis. Penggunaan media filter ini dapat diaktivasi secara kimia, fisika, dan fisikia-kimia untuk memberikan hasil adsorpsi kontaminan yang optimal (Meisrilestari, 2013). Media filter yang disebut sebagai adsorben ini mampu menurunkan konsentrasi kontaminan yang ada pada sumber air maupun lingkungannya.

Beberapa penelitian tentang adsorben sebagai media filter dalam menurunkan kontaminan pada beberapa sumber air atau limbah diantaranya yaitu penelitian yang dilakukan oleh Rizki N. A., 2017 tentang adsorpsi logam $\mathrm{Cu}$ dan $\mathrm{Sn}$ dengan campuran arang aktif dan zeolit alam pada air limbah elektroplatting. Selain itu dilakukan penelitian oleh Dwi Rustam, 2015 tentang media filter zeolite dan karbon aktif dalam menurunkan kontaminan pada air hujan. Media filter zeolite dan arang aktif mampu mengadsorpsi partikel yang cukup besar disebabkan ukuran pori-pori yang terdapat pada media filter tersebut. Sehingga kontaminan pada air seperti logam berat maupun bakteri dapat teradsorpsi secara fisika maupun kimia. Penelitian yang dilakukan oleh Alwin, 2017 juga meneliti tentang teknik filterisasi dengan penggunaan zeolite, pasir, dan arang aktif yang mampu menurunkan kontaminan pada air sumur yang diperkirakan mengandung $\mathrm{Fe}, \mathrm{Mn}$, dan Mg. Berdasarkan hal tersebut, maka pada penelitian ini dilakukan proses filterisasi menggunakan adsorben alami untuk melihat kemampuan adsorben dalam menjerap logam timbal yang terdapat di matriks air sungai.

\section{Metode Penelitian}

Alat dan Bahan

Peralatan yang digunakan pada penelitian ini adalah labu ukur, timbangan analitik, gelas kimia, gelas ukur, spatula, batang pengaduk, pHmeter, oven, 
spektrofotometer AAS (Shimadzu AA 7000). Sedangkan bahan yang digunakan pada penelitian diantaranya asam nitrat, arang aktif (AA), zeolite (Z), sekam padi bakar (SPB), sekam padi (SP), serbuk kayu (SK), serabut kelapa $(\mathrm{CH})$, pasir silica (PS), jerami padi (JP), akuades, $\mathrm{Pb}\left(\mathrm{NO}_{3}\right)_{2} .5 \mathrm{H}_{2} \mathrm{O}$ (merck), kapas dacron.

Prosedur Kerja

Pembuatan media filter dilakukan dengan menyiapkan sejumlah adsorben yang kemudian akan dimasukkan kedalam sebuah galon bervolume 5 liter dengan diameter 16 $\mathrm{cm}$. Ketinggian adsorben yang digunakan yaitu $20 \mathrm{~cm}$ sesuai dengan volume galon. Susunan media filter dari dasar yaitu batu koral, kapas dacron, adsorben, dan ditutup dengan kapas dacron. Untuk adsorben arang aktif sebelumnya dilakukan pencucian dan pengeringan menggunakan oven pada suhu $120^{\circ} \mathrm{C}$ selama \pm 2 jam untuk membuka poripori adsorben menjadi lebih besar. Untuk adsorben jerami padi dilakukan proses pemblenderan untuk memudahkan dalam pengisian kedalam galon filter. Beberapa adsorben lainnya hanya dilakukan pencucian untuk membersihkan dari debu maupun kotoran yang tidak diharapkan sehingga tidak akan mempengaruhi hasil proses filterisasi.

Setiap adsorben dilakukan replikasi sebanyak tiga kali berdasarkan perhitungan rumus rancangan acak lengkap sebagai berikut, dengan $\mathrm{t}$ adalah perlakuan dimana merupakan banyaknya jenis adsorben yang digunakan (Gomez dan Arturo, 1995) :

$$
\begin{gathered}
(\mathrm{t}-1)(\mathrm{r}-1) \geq 15 \\
(8-1)(\mathrm{r}-1) \geq 15 \\
\mathrm{r} \geq 3,14
\end{gathered}
$$

1. Pembuatan larutan induk $\mathrm{Pb} 1000 \mathrm{ppm}$ Menimbang sejumlah 1,59 g timbal nitrat kedalam $1 \mathrm{~L}$ labu ukur dan diencerkan dengan akuadest sampai tanda tera.

2. Pembuatan larutan sampel air sungai Larutan sampel merupakan air sungai yang sudah disampling pada titik lokasi yang telah ditentukan. Kemudian air sungai yang sudah disampling ditambahkan larutan $\mathrm{Pb}$. Larutan timbal yang ditambahkan berasal dari pengenceran $5 \mathrm{~mL}$ larutan induk 1000 ppm Pb kedalam $1000 \mathrm{~mL}$ labu ukur. Satu proses filterisasi adsorben membutuhkan 5 liter sampel kontrol.

3. Proses Filterisasi

Pada proses ini dilakukan tahapan awal yaitu conditioning dengan mengalirkan sampel sebanyak 2 liter yang kemudian dibilas dengan akuadest sebanyak 2 liter. Setelah tahap ini kemudian mengalirkan sampel sebanyak 3 liter dengan pengulangan sebanyak 3 kali untuk satu adsorben. Sampel dialirkan dengan laju alir 0,5 L/menit. Hasil filterisasi kemudian akan diuji dengan spektrofotometer AAS.

4. Analisis Kandungan Logam Timbal

Sampel control dan sampel hasil filterisasi setiap adsorben dilakukan pengukuran kadar timbal dengan spektrofotometer AAS yang dilakukan di Laboratorium Politeknik AKA, Bogor. Pengukuran dilakukan pada panjang gelombang 283,3 $\mathrm{nm}$. Metode pengkuran mengacu pada SNI 06-6989.8-2004.

\section{Hasil Penelitian dan Pembahasan}

Proses penelitian diawali dengan pembuatan sampel larutan yaitu air sungai yang sudah ditambahkan larutan $\mathrm{Pb}$. Sebagai kontrol maka sampel ini dijadikan sebagai dasar untuk melihat perubahan konsentrasi $\mathrm{Pb}$ setelah mengalami filterisasi kedelapan adsorben tersebut. Berikut adalah hasil uji

\begin{tabular}{|c|c|}
\hline Parameter & Hasil \\
\hline $\mathrm{pH}$ & 6,48 \\
\hline Kadar $\mathrm{Pb}(\mathrm{mg} / \mathrm{L})$ & 4,95 \\
\hline $\begin{array}{l}\text { Organoleptik (Rasa, } \\
\text { Bau) }\end{array}$ & $\begin{array}{c}\text { Tidak berasa dan } \\
\text { berbau }\end{array}$ \\
\hline
\end{tabular}
sampel control.

Tabel 1. Hasil Uji Sampel Kontrol Air Sungai

Proses filterisasi dilakukan dengan tahap awal conditioning. Pada tahapan ini bertujuan untuk membersihkan dan mengondisikan adsorben dalam keadaan 
siap pakai jika dialiri dengan sampel kontrol. Untuk adsorben arang aktif diberi pelakuan dengan membersihkan terlebih dahulu dengan air mengalir untuk menghilangkan pengotor yang terdapat pada adsorben. Setelah pembersihkan dilakukan proses pemanasan dengan oven yang bertujuan untuk menghilangkan kadar airnya (Meisrilestari, 2013). Proses ini bertujuan agar pori-pori pada arang aktif dapat menjadi lebih besar, sehingga diharapkan dalam menjerap kontaminan timbal dapat secara optimal. Kandungan pada arang aktif didominasi oleh karbon dimana zat ini mampu menyerap anion, kation, dan molekul senyawa lain baik dalam bentuk organic maupun anorganik serta dalam wujud gas atau larutan (Gustan, 2006). Berikut adalah hasil filterisasi pada kedelapan adsorben yang digunakan.

Tabel 2. Hasil Uji Kadar Timbal pada Sampel Filterisasi Air Sungai

\begin{tabular}{cc}
\hline Adsorben & $\begin{array}{c}\text { Konsentrasi Sesudah } \\
\text { Filterisasi (mg/L) }\end{array}$ \\
\hline CH & $<0,5$ \\
AA & 1,72 \\
Z & $<0,5$ \\
JP & 0,92 \\
PS & 0,81 \\
SPB & 0,87 \\
SP & 1,18 \\
SK & $<0,5$ \\
\hline
\end{tabular}

Untuk melihat penurunan konsentrasi kadar $\mathrm{Pb}$ sebelum dan sesudah filterisasi maka dihitung persentase penurunan kadar menggunakan rumus :

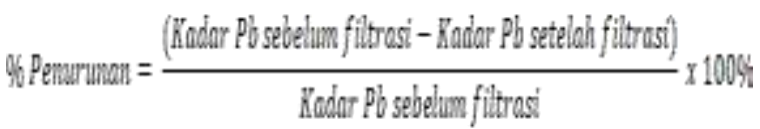

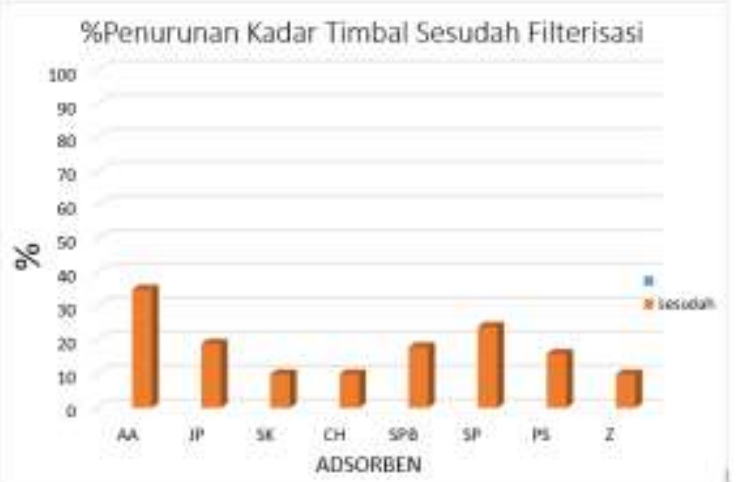

Gambar 1. Grafik Persentase Penurunan Kadar Timbal Sesudah Filterisasi

Berdasarkan gambar 1. terlihat diantara ke-8 adsorben yang memberikan persentase penurunan paling sedikit yaitu arang aktif sebesar 65\%. Sedangkan yang memberikan penurunan kadar timbal sesudah filtrasi paling besar adalah adsorben serbuk kayu, serabut kelapa, dan zeolite yaitu sebesar 90\%. Persentase awal 100\% mengalami penurunan sebesar $90 \%$ sehingga kadar timbal sesudah filtrasi hanya $10 \%$ yaitu $<0,5 \mathrm{mg} / \mathrm{L}$.

Adsorben yang digunakan pada penelitian ini pada umumnya dapat ditemukan dengan mudah dan berbahan alami. Kemampuan adsorben serbuk kayu dan serabut kelapa dalam menjerap kontaminan logam $\mathrm{Pb}$ dikarenakan adanya kandungan lignin dan selulosa yang mampu mengadsorpsi logam tersebut. Senyawa lignin mengandung asam fenolat dan selulosa mengandung gugus karboksil yang membantu proses adsorpsi dalam pengikatan logam (Fitria, 2017). Kandungan lignin dan selulosa pada serabut kelapa sekitar 35-45\% dan 23-43\% (Faslah, 2013). Sedangkan pada serbuk kayu juga dapat menjerap logam berat sejalan dengan penelitian yang dilakukan Sulistyo, 2016 dalam menjerap logam $\mathrm{Cd}$ yang termasuk logam berat. Untuk zeolite juga memberikan penurunan kontaminan yang besar disebabkan rongga dan pori yang dimiliki cukup besar sehingga dapat ditempat oleh 
molekul air maupun kation dalam hal ini logam timbal (Yulius, 2019)

Pengukuran $\mathrm{pH}$ juga dilakukan untuk mengetahui kondisi sampel setelah mengalami proses filterisasi pada kedelapan adsorben. Nilai $\mathrm{pH}$ ini dapat digunakan sebagai acuan apakah air hasil filterisasi mengalami perubahan suasana menjadi lebih asam atau lebih basa atau netral. Berikut adalah grafik nilai pH pada sampel sesudah filtrasi, dengan control adalah nilai $\mathrm{pH}$ awal sampel sebelum filterisasi.

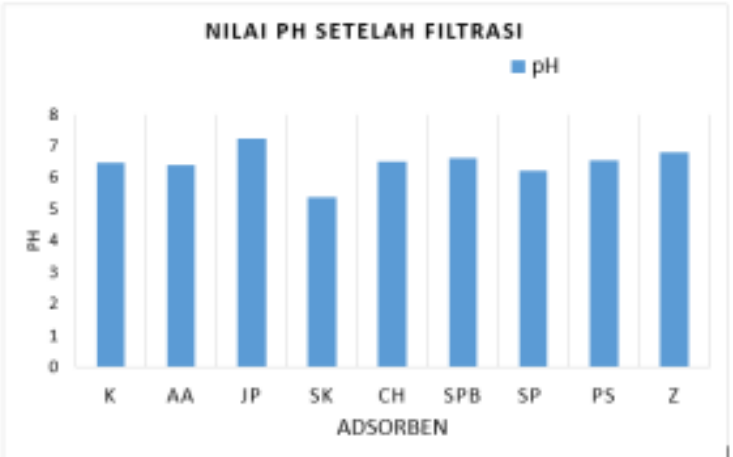

Gambar 2. Nilai pH Sesudah Filterisasi

Pada gambar 2 terlihat perubahan nilai pH untuk setiap sampel hasil filterisasi pada kedelapan adsorben. Perubahan nilai $\mathrm{pH}$ oleh adsorben jerami padi terlihat lebih besar dibanding hasil filterisasi pada adsorben lainnya. Sedangkan penurunan nilai pH terlihat pada hasil filterisasi menggunakan adsorben serbuk kayu. Jika dirata-ratakan perubahan nilai $\mathrm{pH}$ antara sebelum dan sesudah filterisasi tidak terlalu beda jauh. Maka proses filterisasi ini tidak terlalu menyebabkan perubahan nilai $\mathrm{pH}$ yang signifikan. Pengukuran nilai $\mathrm{pH}$ dilakukan dengan pHmeter dimana nilai $\mathrm{pH}$ mempengaruhi proses adsorpsi zat kontaminan dengan adsorben. Tingkat keasaman larutan akan mempengaruhi muatan aktif pada adsorben dan spesiasi bentuk logam. Menurut Maulidha, 2016 yaitu pada kondisi $\mathrm{pH}$ asam terjadi kompetisi antara $\mathrm{Pb}^{2+}$ dengan $\mathrm{H}^{+}$pada permukaan adsorben, sedangkan saat $\mathrm{pH}$ mendekati kebasaan maka akan terbentuk endapan
$\mathrm{Pb}(\mathrm{OH})_{2}$ sehingga menghalangi proses penjerapan logam $\mathrm{Pb}$.

Selanjutnya dilakukan pengujian statitistika uji paired t-test menggunakan SPSS V.23. Uji ini dilakukan untuk mengetahui pengaruh varibel bebas terhadap variable terikat dalam penelitian. Pemilihan uji ini untuk mengetahui perbedaan rata-rata dua kelompok yang berpasangan. Berdasarkan perhitungan uji tersebut diperoleh hasil yaitu nilai Sig (2tailed) $<\alpha=0,025$. Hal ini menandakan adanya beda nyata rata-rata kadar logam $\mathrm{Pb}$ antara sebelum dan sesudah filterisasi pada penelitian. Hasil oleh statistika tertuang pada tabel dibawah ini.

Tabel 3. Uji Paired T-Test

\begin{tabular}{|c|c|c|c|c|c|}
\hline & \multicolumn{2}{|c|}{$\begin{array}{c}\text { Paired } \\
\text { Differences }\end{array}$} & \multirow[b]{2}{*}{$\mathrm{t}$} & \multirow[b]{2}{*}{$\mathrm{df}$} & \multirow[b]{2}{*}{$\begin{array}{l}\text { Sig. (2- } \\
\text { tailed) }\end{array}$} \\
\hline & Mean & $\begin{array}{c}\text { Std. } \\
\text { Devia } \\
\text { tion }\end{array}$ & & & \\
\hline Sebelum & 4,074 & .4017 & 49,6 & 2 & .000 \\
\hline $\begin{array}{l}\text { _Filter } \\
\text { Setelah_ } \\
\text { Filter }\end{array}$ & 58 & 7 & 84 & 3 & \\
\hline
\end{tabular}

\section{Simpulan}

Berdasarkan hasil penelitian yang diperoleh dapat disimpulkan bahwa kedelapan adsorben mampu menjerap logam timbal. Hal ini ditunjukkan dari penurunan kadar logam timbal sebelum dan sesudah proses filterisasi dengan adsorben tersebut. Diantara kedelapan adsorben yang menunjukkan penurunan logam timbal terbesar adalah zeolite, serbuk kelapa, dan serbuk kayu. Perubahan nilai $\mathrm{pH}$ antara sebelum dan sesudah filterisasi tidak menunjukkan perubahan yang signifikan. Berdasarkan uji paired t-test terlihat perbedaan yang nyata antara sebelum dan sesudah filterisasi dengan nilai Sig (2-tailed) yaitu $.000<\alpha ́ \alpha=0.025$ 


\section{Ucapan Terima Kasih}

Penulis berterima kasih kepada semua pihak yang turut membantu dalam riset ini dan kepada Poltekkes Kemenkes Banten yang telah mendanai riset ini yang bersumber dari DIPA Poltekkes Tahun 2019.

\section{Daftar Pustaka}

Arifah R.N, Susila K. 2015. Penggunaan Campuran Arang Aktif dengan Zeolite Alam Untuk Adsorpsi Logam Tembaga dan Seng. Skripsi. Yogyakarta. UNY

Cahyani, Fitria Nur. 2017. Efektivitas Biofilter Berbahan Sabut Kelapa Dengan Penambahan Serbuk Biji Kurma dan Serbuk Biji Kopi Terhadap Emisi Partikel Ultrafine dan Radikal Bebas Rokok. Skripsi, tidak dipublikasikan. Universitas Islam Negeri Maulana Malik Ibrahim

Dini, Maulidha Kurnia, dkk. 2016. Potensi Jerami Sebagai Adsorben Logam Timbal (Pb) Pada Limbah Cair Industri Batik Sidokare, Sidoarjo. LenteraBio Vol.5 No.3, September 2016.

Dwi R K, dkk. 2015. Penggunaan Filter Zeolite dan Karbon Aktif Untuk Menurunkan Sisa Klor dan Peningkatan pH Air Hujan. Bandung. Universitas Padjajaran.

Faslah, Ferdian. 2013. Pengaruh Penggunaan Filter Berbahan Serabut Kelapa Terhadap Emisi Partikel Ultrafine Asap Mainstream Rokok. Skripsi. Malang : Universitas Brawijaya.

Fibrianti D, Azizah R. 2015. Karakteristik kadar timbal $(\mathrm{Pb})$ dalam darah dan hipertensi pekerja home industry aki bekas di Desa Talun Kecamatan Sukodadi Kabupaten Lamongan.
Jurnal Kesehatan Lingkungan. 8 (1) : $92-102$.

Gomez.K.A and Gomez. A.A. Statistical Procedures For Agricultural Research. John Wiley \& Sons, Inc. 1995.

Meisrilestari, Yessy, dkk. Pembuatan Arang Aktif Dari Cangkang Kelapa Sawit Dengan Aktivasi Secara Fisika, Kimia, dan Fisika-Kimia. Konversi Volume 2 No.1, April 2013

Mifbakhudin. 2010. Pengaruh Ketebalan Karbon Aktif Sebagai Media Filter Terhadap Penurunan Kesadahan Air Sumur Artetis. Semarang: Vol 5 (2).

Mugiyantoro, Alwin, dkk. 2017. Penggunaan Bahan Alam Zeolit, Pasir Silika, dan Arang Aktif Dengan Kombinasi Teknik Showe Dalam Filterisasi Fe, Mn, dan Mg Pada Air Tanah Di UPN Veteran Yogyakarta. Proceeding. Yogyakarta.

Ngapa, Yulius Dala. Jumilah Gago. 2019. Adsorpsi ion Pb(II) Oleh Zeolit Alam Ende Teraktivasi Asam:Studi Pengembangan Mineral Alternatif Penjerap Limbah Logam Berat. Cakra Kimia (Indonesia E-Journal of Applied Chemistry) Volume 7 No.2.

Novia, Ajeng Ari, dkk. Alat Pengolahan Air Baku Sederhana Dengan Sistem Filtrasi. Widyakala Volume 6 Special Issue Juli 2019 PP 12-20.

Rustan, Fathur Rahman, dkk. 2019. Analisis Pemakaian Air Bersih Rumah Tangga Warga Perumahan Bumi Mas Graha Asri Kota Kendari. Stabilita Jurnal Ilmiah Teknik Sipil. Volume 7, Nomor 2, Juni 2019. 
Saputro, Sulistyo. Amela, Retnaningrum.

2016. Penggunaan Serbuk Gergaji

Kayu Jati Sebagai Adsorben Ion

Logam Cd(II) dan Analisisnya

Menggunakan Solid-Phase

Spectrophotometry (SPS). Prosiding

Seminar Nasional Pendidikan Sains (SNPS), Surakarta 22 Oktober 2016.

Suyasa, Wayan Budiarsa. 2015. Pencemaran Air \& Pengolahan Air Limbah. Bali : Udayana University Press 